http://dx.doi.org/10.11646/phytotaxa.175.3.3

\title{
A new tree species of Schinopsis (Anacardiaceae) from Paraguay and Bolivia
}

\author{
VIRGINIA Y. MOGNI ${ }^{1,2 *}$, LUIS J. OAKLEY ${ }^{1}$, MARÍA VERA JIMÉNEZ ${ }^{3} \&$ DARIÉN E. PRADO ${ }^{1,2}$ \\ ${ }^{1}$ Cátedra de Botánica, Facultad de Ciencias Agrarias, Universidad Nacional de Rosario. Campo Experimental Villarino, S2125ZAA \\ Zavalla, Provincia de Santa Fe, Argentina. \\ ${ }^{2}$ Consejo Nacional de Investigaciones Cientificas y Técnicas (CONICET). \\ ${ }^{3}$ Laboratorio de Análisis de Recursos Vegetales. Facultad de Ciencias Exactas y Naturales, Universidad Nacional de Asunción, Para- \\ guay. \\ *Corresponding author: virginia.mogni@unr.edu.ar
}

\begin{abstract}
The new tree species Schinopsis boqueronensis, endemic to the Bolivian-Paraguayan Chaco, is described, illustrated and compared to the related Schinopsis heterophylla. A distribution map and photographs of the new species are also provided.
\end{abstract}

Key words: Boquerón, Chaco, South America, taxonomy

\section{Introduction}

The genus Schinopsis Engl. (1876: 403) (Subfamily Anacardioideae, Family Anacardiaceae, Order Sapindales; Judd et al., 1999; Pell, 2004) has a restricted geographical distribution in the Seasonally Dry Tropical Forests (SDTF, sensu Prado, 2000), but is also found in the subtropical Chaco forests (Prado 1993a, b) of South America. It is a small genus of very important cultural and economic influence in the continent, characterized by its timber of extreme durability and toughness (Barberis et al., 2012). The species of Schinopsis are also of ecological importance because are usually dominant or co-dominant in the environments where they grow.

Meyer \& Barkley (1973) included seven species in Schinopsis and placed S. heterophylla Ragonese \& J. A. Castigl. (1947: 98) as a synonym of S. quebracho-colorado (Schltdl., 1861: 139) F.A. Barkley \& T. Mey. (1950: 156), which in turn has been placed as a synonym of S. lorentzii (Griseb., 1874: 115) Engl. (1881: 46). S. heterophylla was originally described from the Argentinean Chaco. Recently, Muñoz (1990) reinstated S. heterophylla as a distinct species, and indicated the presence of newly collected specimens in Bolivia and Paraguay.

During the preparation of a revision of Schinopsis, the authors of the present contribution found a number of herbarium specimens collected in Bolivia and Paraguay that were identified as S. heterophylla, but have morphological characters that do not correspond to Ragonese \& Castiglioni's (1947) original description of the species. A thorough morphological analysis of the specimens, together with the collection of fresh material in the field in the Paraguayan Chaco in 2011, led us to propose here a new arboreal species, Schinopsis boqueronensis. A key to distinguish the new species from $S$. heterophylla, together with illustrations, photographs and a distribution map of $S$. boqueronensis are provided.

\section{Materials and methods}

Herbarium specimens at CTES, FCQ, LIL, PY and SI (Index Herbariorum, Holmgren et al., 1990) were studied. Additionally, new material collected in central-western Paraguayan Chaco in December 2011 (deposited in FCQ, Asunción) was also included in the analysis.

At present, the proper administrative processes are being followed in order to formally distribute duplicates of specimens from FCQ herbarium in the near future.

Morphological characters were studied using digital calliper and a stereoscopic microscope, and are here described using the terminology used by Ragonese \& Castiglioni (1947), Barkley (1962), Meyer \& Barkley (1973), and Muñoz (1990). 


\section{Identification key to distinguish $S$. boqueronensis from $S$. heterophylla:}

1. Simple leaves glaucous, generally oblong-lanceolate; apex acute to gradually emarginate; base sometimes lobate; secondary veins prominent but inconspicuous in colour, with a divergence of $55^{\circ}$ to $60^{\circ}$ from the principal vein. Petals 5. Samara without lignified styles.

S. heterophylla Simple leaves green and shiny on the upper surface, lighter and grey below, generally oblong-ovate; apex emarginate, obtuse to sub-acute; base rarely lobate; secondary veins pallid, with a divergence of $60^{\circ}$ to $90^{\circ}$ from the principal vein. Petals 5 , occasionally 6. Samara with noticeable lignified styles S. boqueronensis

Finally, it is worth noting that the new species described presents morphological characters intermediate between $S$. cornuta and S. lorentzii, with which it coexists in the field. A similar situation has been observed for S. heterophylla, considered a possible hybrid between S. balansae Engl. (1885: 286) and S. lorentzii (Ragonese \& Castiglioni, 1947, Anzótegui, 1971, and Del Pero de Martínez, 1972).

\section{Acknowledgements}

We thank the curators of the herbaria CTES, FCQ, LIL, PY and SI for providing material for this study, Roberto Kiesling and Jefferson Prado for their invaluable help with the Latin diagnosis, Harumi Arakaki for English language assessment and Gwilym Lewis for his critical reading of the manuscript. We also thank Luciana Delgado for the botanical illustrations and Germán González and Christian Vogt for their assistance during fieldwork. The authors thank two anonymous reviewers for their very helpful and constructive comments and CONICET-Consejo Nacional de Investigaciones Científicas y Técnicas (PIP 0858) and National University of Rosario, Argentina, for funding and facilities to perform this work.

\section{References}

Anzótegui, L.M. (1971) El polen de las Anacardiaceae del N.E. de la Argentina. Ameghiniana 8: 329-340.

Barberis, I.M., Mogni, V.Y., Oakley, L.J., Alzugaray, C., Vesprini, J.L. \& Prado, D.E. (2012) Biología de especies australes: Schinopsis balansae Engl. (Anacardiaceae). Kurtziana 37: 59-86.

Barkley, F.A. \& Meyer, T. (1950) El nombre botánico del “quebracho colorado santiagueño”. Boletín de la Sociedad Argentina de Botánica 3: $155-156$.

Barkley, F.A. (1962) Anacardiaceae: Rhoideae: Schinopsis. Proceedings of the Iraqi Scientific Societies 5: 44-69.

Barneby, R.C. \& Fortunato R.H. (1987) Four new diplostemonous species of Mimosa (Mimosaceae) from Paraguay and Eastern Bolivia. Brittonia 39: 165-174. http://dx.doi.org/10.2307/2807367

Barneby, R.C. \& Grimes, J.W. (1996) Silk Tree, Guanacaste, Monkey’s Earring. Memories of The New York Botanical Garden 74(1): $1-292$.

Burkart, A. (1947) Leguminosas nuevas o críticas, II. Darwiniana 7: 504-540.

Del Pero de Martínez, M.A. (1972) Hibridación en el género Schinopsis. Resúmenes XII Jornadas Argentinas de Botánica, 2-5 Noviembre 1972, Neuquén, Argentina.

Engler, H.G.F. (1876) Anacardiaceae. In: Martius, C.F.P. von (Ed.) Flora Brasiliensis, vol. 12, part 2. F. Fleischer, Monachii \& Lipsiae, pp. $367-418$.

Engler, H.G.F. (1881) Diagnosen neuer Burseraceae und Anacardiaceae. Botanische Jahrbücher für Systematik 1: 41-47.

Engler, H.G.F. (1885) Eine neue Schinopsis. Botanische Jahrbücher für Systematik 6: 286.

Fortunato, R.H. \& Cialdella, A.M. (1996) Una especie nueva del género Acacia (Acacieae, Mimosoideae, Fabaceae) para el Chaco boliviano-paraguayo: A. emilioana Fortunato \& Ciald. Discusión sobre su ubicación infragenérica. Contribución al estudio de la flora y vegetación del Chaco. X. Candollea 51: 215-224.

Grisebach, A.H.R. (1874) Plantae Lorentzianae. Abhandlungen der Königlichen Gesellschaft der Wissenschaften zu Göttingen 19: 49279.

Grisebach, A.H.R. (1879) Symbolae ad Floram Argentinam. Abhandlungen der Königlichen Gesellschaft der Wissenschaften zu Göttingen 24:1-346.

Holmgren, P., Holmgren, B. \& Barnett, L. (1990) Index Herbariorum. Part I: The herbaria of the World. $8^{\text {th }}$ ed. Regnum Vegetabile, vol. 120. New York Botanical Garden, New York, USA, 693 pp.

Hooker, W.J. \& Arnott, G.A.W. (1833) Contributions towards a Flora of South America and the Island of the Pacific. Botanical Miscellany 3(8): 129-211.

Hunziker, A. \& Dottori, N. (1976) Contribución al conocimiento sobre los talas (Celtis, Ulmaceae) de Argentina, con especial referencia a la región mediterránea I. Sobre una especie Austrosudamericana y sobre otra de área disyunta. Kurtziana 9: 103-140. 
Judd, W.S., Campbell, C.S., Kellogg, E.A. \& Teven, P.P. (1999) Plant Systematics: A Phylogenetic Approach. 2nd ed. Sinauer Associates, Sunderland, Mass., USA, 576 pp.

Klotzch, J.F. (1847) Beiträge zu einer Flora der Aequinoctial-Gegenden der Neuen Welt. Linnaea 20: 337-542. http://dx.doi.org/10.5962/bhl.title.6148

Kuntze, C.O. (1898) Revisio Generum Plantarum 3(3): 1-576. A. Felix, Leipzig.

Liebmann, F.M. (1851) Mexicos Halvgraes. Kongelige Danske videnskabernes Selskabs Skrifter, Naturvidenskabeli Mathematisk Afdeling ser. 5, vol. 2: 4-513.

Loesener, L.E.T. \& Herzog, T.C.J. (1915) Herzog's bolivianische Pflanzen II: Anacardiaceae. Mededeelingen van's Rijks-Herbarium 27: $84-88$.

Martius, C.F.P. von (1824) Nova Genera et Species Plantarum Brasiliensium, vol.1. Typis Lindaueri, Munich, 158 pp.

Martius, C.F.P. von (1841) Beiblätter zur Flora oder Allgemeinen Botanischen Zeitung. Flora 24 (2 Beibl.): 1-112.

Mereles, M.F. (2005) Una aproximación al conocimiento de las formaciones vegetales del Chaco boreal, Paraguay. Rojasiana 6(2): $5-48$.

Meyer, T. \& Barkley, F.A. (1973) Revisión del género Schinopsis (Anacardiaceae). Lilloa 33: 207-257.

Moore, S.L.M. (1895) The Phanerogamic Botany of The Matto Grosso Expedition, 1891-92. Transactions of the Linnean Society of London, Botany 4: 265-516. http://dx.doi.org/10.1111/j.1095-8339.1895.tb00046.x

Muñoz, J.D. (1990) Anacardiaceae. In: Spichiger, R. \& Ramella, L. (Eds.) Flora del Paraguay. Missouri Botanical Garden \& Conservatoire \& Jardin Botaniques de la Ville de Genève, Geneva, 5-84 pp.

Navarro G. (2004) Mapa de Vegetación del Parque Nacional y ANMI KAA-IYA del Gran Chaco. WCS. FAN, Santa Cruz de la Sierra, Bolivia, $42 \mathrm{pp}$.

Navarro, G., Molina, J. \& Pérez de Molas, L. (2006) Classification of the forests of the northern Paraguayan Chaco. Phytocoenologia 36(4): 473-508. http://dx.doi.org/10.1127/0340-269x/2006/0036-0473

Oakley, L.J. \& Prado, D.E. (2013) Nueva combinación en Celtis ehrenbergiana (Klotzsch) Liebm. Rojasiana 12: 125-129.

Pell, S.K. (2004) Molecular systematics of the cashew family (Anacardiaceae). PhD Dissertation, Louisana State University, Baton Rouge, 193 pp.

Philippi, R.A. (1870) Sertum mendocinum alterum, o sea, catálogo de las plantas recojidas cerca de Mendoza i en los caminos que conducen de Chile a esa ciudad. Anales de la Universidad de Chile 36: 159-212.

Prado, D.E. (1991) A critical evaluation of the floristic links between Chaco and Caatingas vegetation in South America. PhD Dissertation, St. Andrews University, St. Andrews, 283 pp.

Prado, D.E. (1993a) What is the Chaco vegetation in South America? I. A review. Candollea 48: 145-172.

Prado, D.E. (1993b) What is the Chaco vegetation in South America? II. A redefinition. Candollea 48: 615-629.

Prado, D.E. (2000) Seasonally dry forests of tropical South America: from forgotten ecosystems to a new phytogeographic unit. Edinburgh Journal of Botany 57: 437-461. http://dx.doi.org/10.1017/s096042860000041x

Ragonese, A. \& Castiglioni, J. (1947) Nueva especie del género Schinopsis y área geográfica de las especies argentinas. Revista de Investigaciones Agrarias 1: 93-100.

Sánchez, A. \& Kron, K.A. (2011) Phylogenetic Relationships of Triplaris and Ruprechtia: Re-delimitation of the Recognized Genera and Two New Genera for Tribe Triplaridae (Polygonaceae). Systematic Botany 36: 702-710. http://dx.doi.org/10.1600/036364411x583664

Schlechtendal, D.F.L. von (1861) Ueber den Quebracho der argentinischen Staaten nach Prof. Burmeister's Mittheilungen. Botanische Zeitung (Berlin) 19: 137-140.

Schott, H. (1827) Appendix: Fasciculus Plantarum Brasiliensium. In: Sprengel, K.P. (Ed.) Systema Vegetabilium 16. Sumtibus Librariae Dieterichianae, Göttingae, 403-410 pp.

Seigler, D. \& Ebinger, J. (2005) New combinations in the genus Vachellia (Fabaceae: Mimosoideae) from the New World. Phytologia 87(3): 139-178.

Seigler, D. \& Ebinger, J. (2006) The genus Senegalia (Fabaceae: Mimosoideae) from the New World. Phytologia 88(1): 38-93.

Silva Manso, A.L.P. (1836) Enumeração das Substancias Brazileiras que podem promover a catarze. Imperial Academia de Medicina do Rio de Janeiro, Rio de Janeiro, $72 \mathrm{pp}$. http://dx.doi.org/10.5962/bhl.title.42855

Spichiger, R, Calenge, C \& Bise, B. (2005) Discriminant analysis of the spatial distribution of plant species occurrences: II. Distribution of major tree communities in Paraguay. Candollea 60: 577-593.

Sprengel, K.P. (1827) Systema Vegetabilium (Ed. 16) 4(2): 1-410. Sumtibus Librariae Dieterichianae. Göttingae. http://dx.doi.org/10.5962/bhl.title.822

Tulasne, L.R. (1843) Nova quaedam genera in Leguminosarum classe. Annales des Sciences Naturelles; Botanique, séries. 2 20: $136-144$. 